\title{
Job satisfaction from leadership perspective
}

\author{
Fazal HALEEM \\ Abdul Wali Khan University Mardan, Pakistan \\ haleemfazal@gmail.com \\ Muhammad JEHANGIR \\ Abdul Wali Khan University Mardan, Pakistan \\ jehangir@gmail.com \\ Muhammad KHALIL-UR-RAHMAN \\ Abdul Wali Kahn Univesity Mardan, Pakistan \\ khalilhr04@gmail.com
}

\begin{abstract}
Transformational leaders encourage their subordinates to achieve organizational goals and objectives and to reach their full potential by providing the needed resources. This increasing influence of transformational leaders on employees instigated us to find out the impact of transformational leadership on employees' job satisfaction. The study was conducted in the public sectors universities of KPK, Pakistan. A sample size of 130 employees was selected using convenient sampling techniques. The data was collected from grade 16 and upper level of employees in the universities. Initially, 130 questionnaires were sent out to the target population for their participation in the survey; out of which 100 filled questionnaires were received forming percentage of 76.92\%. These 100 properly filled questionnaires were used for statistical analysis. Both descriptive and advance multivariate statistical, correlation and regression analysis, were conducted to get a feel for the data and to test the postulated hypothesis respectively. Findings of the study revealed that there was non-significant influence of transformational leadership in terms of idealized influence, individualized consideration, and inspirational motivation on employees' job satisfaction in the public sectors universities of KPK, Pakistan. However, the intellectual stimulation type of leadership had positive and significant impact on employees' job satisfaction. The paper contributes to the literature review in context of non-forprofit organizations in a developing country and provides implications for universities' executives to pay more attention to intellectual stimulation type of leadership to increase employees' satisfaction and thus help achieve the universities goals and objectives.
\end{abstract}

Keywords: transformational leadership, idealized influence, individualized consideration, inspirational motivation, intellectual stimulation, employees' job satisfaction, universities, higher education.

\section{Introduction}

Organizations are social system in which the most valuable asset is human resources that help achieve organizational efficiency and effectiveness. Human resources play important role in accomplishing firms' goals and objectives (Mosadragh, 2003). The modern business world characterized by globalization and advanced technologies put pressure on firms to become more competitive and outperform its competitors especially in the domain of human resource competence. Recruiting and selecting employees from different regions, cultures and background is a difficult task and is highly influenced by the leadership style of the recruiting firm (Albion \& Gagliardi, 2007). 
The success of organization depends upon the involvement, efforts, and commitment of their labor or workforce. The main factor for organizational effectiveness is manager's leadership style. In present time organizations are more concerned about developing, understanding and modifying their leadership style in line with firm's strategy, structure and system. Leadership style has deep relevance and influence on the human resources of a firm in terms of attracting people to achieve the goals of organizations (Skansi, 2000). A transformational leader encourages his/her subordinates to achieve organizational goals and objectives and to reach their potential by providing the mandatory resources (Ansari \& Arasto, 2006). In addition, transformational leaders motivate and encourage their subordinates to enhance their learning in terms of skills set and knowledge. They also act as a role a model and provide an encouraging work environment to their subordinates (Hassan, 2013).

Boss \& Avolio (1998) categorize transformational leadership into four categories. These categories are idealized influence in terms of attributes and behavior, inspirational motivation, individual consideration and intellectual stimulation. Socialized personality of a leader whether he/she is perceived as being confident and committed to high order targets is referred to idealized influence (attributed). Similarly idealized influence refers to the compelling actions of the leader that is based on the values, beliefs or ideas. Moreover, the degree of support of the leader to his or her followers in terms of mentoring, encouraging and maintaining followers to self-actualization is termed as individual consideration. Furthermore, the degree of inspiration on which the leader is inspired and appeals to his or her followers is termed as inspirational motivation. In addition, the intellectual extent in which a leader engages his/her followers in thinking and understanding complex ideas is termed as intellectual stimulation.

Leadership style plays a vital role in influencing employee's job satisfaction. Job satisfaction is the behavior and attitude of an employee towards his job and organization that is highly influenced by the work process and environment (Mosadegh \& Yar, 2006). Likewise, both negative and positive feelings of an employee towards his/her job determine employee's job satisfaction that is a key factor in increased productivity and organizational success (Sarri \& Judge, 2004).

From the literature, it is noted that most of the researchers argue that transformational leadership has impact on employee's job satisfaction. Limited study is available regarding transformational leadership and its impact on employee's job satisfaction especially in a non-for-profit and a developing country context such as Pakistan. Thus the purpose of the study is to find out the impact of different styles of transformational leadership on employees' job satisfaction in the public sectors universities of KPK, Pakistan.

\section{Literature review}

The systematic study of leadership began in early 1930s with the study of the "great man" (House \& Aditya, 1997). The scholar was interested in to find the traits and quality of leadership which could distinguish leaders from non-leaders. In spite of the hard work to this area, only some of the traits and qualities of a leader were found positively related to the leader appearance and leadership effectiveness. The word "leadership" in the organization deals with the approaches adopted by superiors in the daily activities with the

DOI: $10.2478 /$ picbe-2018-0032, pp. 363-373, ISSN 2558-9652| Proceedings of the $12^{\text {th }}$ International Conference on Business 
worker. It includes many dimensions like standards, norms, items or issues observed in job condition and effect on worker emotions performance, personality and behavior (Lock \& Crawford, 2004).

Researchers noted that leadership is one of the most important topics in all over the world (Kuchler, 2008). Moreover, leadership is the process of convincing people for the accomplishing the desired goals or outcomes (Jong \& Hartog, 2008). In addition, researchers argued that leadership plays a significant role in determining the success or failure of a firm (Lock \& Crawford, 2009). Thus a leader motivates, stimulates, encourages and directs their followers to accomplish the desired results (Gill, 2009).

A leader guides his or her subordinates to do work as a team player and to contribute in attaining a firm's goals and objectives (Weihrich \& Koontz, 2010). Even if a subordinate does not agree with his or her boss though he/she will accept the influence of his boss because of his or her power or position (Cialdini, 2010). Effective leader will take his or her subordinates with them by developing and making them as important members of the team (Bennis \& Nanus, 2011). Similar view of leadership is shared by the researchers who believe that instead of providing vision and guidelines to the followers, leaders are needed to support, cooperate, coordinate and to direct the team efforts towards the accomplishment of common purpose and goals of the firm (Morgan, 2012).

\section{Transformational leadership}

The concept of transformational leadership was initially introduced by Gregor Burns, a leadership expert, in the $20^{\text {th }}$ century. Burns, being aware of the nature of organizations as open system, focused on the value of the contemporary types of leadership and the associated human resources. Burns (1978) define transformational leaders as a leader who supports, cooperates and encourages his or subordinates to raise their moral level, motivational level, perceptions, beliefs and perception in achieving the goals and objective of the organization. The leadership theory of Burns explains that workers under the influence of a transformational leader will exceed their normal work expectations (Bass, 1985).

\section{Components of transformational leadership}

Avolio et al., (1995) propose four components of transformational leadership: idealized influence, individualized consideration, intellectual stimulation and inspirational motivation.

\section{Idealized influence}

This type of leadership is originally known as charisma. A leader with idealized influence is perceived by his followers as a strong role model with exceptional skills set and high principles of high morality and ethics (Avolio et al., 1995). Moreover, researchers noted that idealized influence is a component of transformational leadership that has very strong and positive relationship with the efforts of the subordinates at work (Bycio, Hackett \& Allen, 1995). In addition, an idealized influence leader takes risk while maintains relevant actions of ethics and conduct (Bass \& Riggio, 2006). 


\section{Individualized consideration}

Individualized consideration is the type of leadership that takes into account the needs of each and every individual and catering to those needs to help the subordinates to work with their full potential (Bass \& Avolio, 1990). More explicitly, a leader with individualized consideration provides customized socio-emotional support to his or her subordinate to help them reach self-actualization (Bass \& Avolio, 1990).

\section{Intellectual stimulation}

Intellectual stimulation type of leadership is related with the activities of the leader to promote culture of challenge, creativity, and innovation among subordinates. This is done by providing the necessary resources and encouraging the subordinates to do things differently and to seek solutions to problems in new ways (Hatter \& Bass, 1988). The positive effects of intellectual stimulation type of leadership has been proved by Bycio et al., (1995) in their research which showed that intellectual stimulation type of leadership had strong positive effect on putting more efforts by followers.

\section{Inspirational motivation}

Inspirational motivation is the way in which the leaders motivate and attract their followers to achieve the organizational goals and objectives and to be optimistic about the future (Bass, 1985). The inspiration motivation leaders expertly communicates the organization's vision and mission to his subordinates and inspire them to accept, follow and commit to the vision and mission of the organization (Shirbu \& Darshan, 2011).

\section{Employee's job satisfaction}

Job satisfaction has been discussed in several studies and researchers have considered it both as dependent variable and independent variable. Researchers have investigated different aspects of job satisfaction such as its types and determinants. Satisfaction is a feeling of a human being towards certain activities influenced by extrinsic and intrinsic components. As far as the job satisfaction is concerned, it is a multi-dimensional concept that depends on number of factors such as pay, supervision, promotion, working condition, organizational practices and relationship with co-workers (Misener, et al., 1996; Spector, 1997). Moreover, job satisfaction is also influenced by positive and effective job orientation (Price \& Muller, 1997), and the extent to which an employee likes his or her job (Stamps, 1997). Mosadeghrad (2003) notes three aspects of job satisfaction, that is, sense of duty of the worker, the job environment, and the job contents. Furthermore, job satisfaction is preset inside in the psyche of a person where an employee will express the level of his or job satisfaction (Stone \& Petterson, 2003). In addition, when the workers are satisfied with their jobs, they form positive and pleasant attitudes towards their jobs. On the other hand if employees are dissatisfied from their jobs, they form negative and unpleasant attitudes towards their job (Armstrong, 2003). Job satisfaction is an attitude which is related with attitude towards life and service quality (Illes et al., 2009).

\section{Transformational leadership and employee's job satisfaction}

A surge in research on the association between transformational leadership and job satisfaction can be traced back to 1920. . Similarly, Northouse (2004) reported that a 
number of researchers, from 1950 to 1960, investigated the association between leadership and job satisfaction in an attempt to increase the satisfaction level of employees on job. In this connection, researchers including Chen and Spector (1991, Brockner (1988) and DeCremer (2003) found significant impact of leadership quality on employees' job satisfaction and self-confidence. Similarly observations have been noted by Al-Ababneh (2013), who argues that leaders who cooperate and support their subordinates outperform those leaders with who do not cooperate and support their subordinates. This suggests that leadership style can be seen as symbol of employees' job satisfaction. By the same token, Yousaf (2000) found out positive association between leaders' behavior and employee's job satisfaction. Thus a leader should act as role model for his/her followers. However, followers have been found to take more interest in transformational leaders than transactional leaders (Druskat, 2000). In addition, a positive and significant impact of transformational leadership on organizational effectiveness has been witnessed (Ristow et al., 2003). Moreover, Gill et al., (2010) noted negative association between transformational leadership and absenteeism.

On the basis of literature review, we postulate the following hypothesis:

$\mathrm{H}_{1}$ : Idealized influence has significant relationship with employees' job satisfaction.

$\mathrm{H}_{2}$ : Individualized consideration has significant relationship with employees' job satisfaction.

$\mathrm{H}_{3}$ : Inspirational motivation has significant relationship with employees' job satisfaction.

$\mathrm{H}_{4}$ : Intellectual stimulation has significant relationship with employees' job satisfaction.

The conceptual model of this study is given below which shows dependent variable job satisfaction relationship with independent variable transformational leadership style domains.

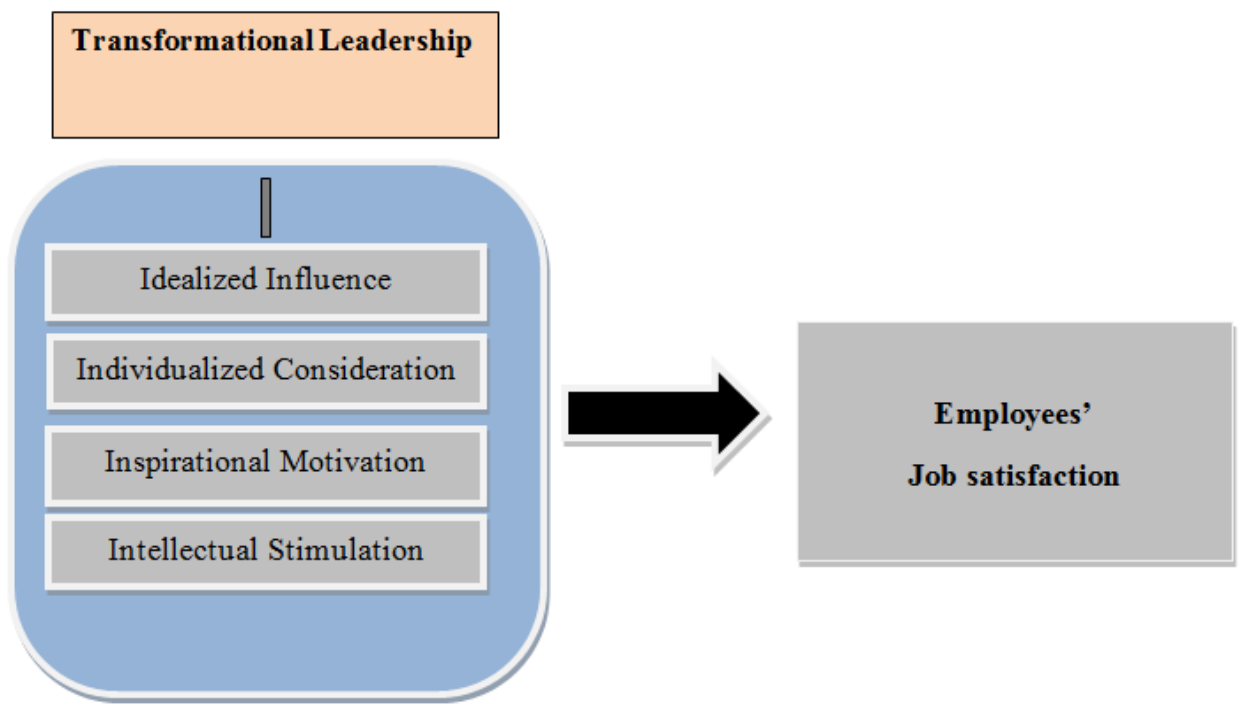

Figure 1. Conceptual model

Source: Based on Avolio et al. (1995).

\section{Methodology}

This section contains brief discussion of population, sample, data collection instrument, procedure and statistical methods, followed by results analysis conducted in SPSS. 


\section{Population and sample}

This study was conducted in the public sectors universities of KPK, Pakistan. Using convenient sampling technique, we sent out 130 questionnaires and received 100 properly filled in questionnaires. A sample size of 100 employees was selected using convenient sampling techniques. The data was collected from Grade 16 and upper level of employees.

\section{Data Collection Instrument}

With the help of self-administered questionnaires, the primary data was collected. Transformational leadership questionnaires was adopted from the study of Avolio, Bass \& Jung (1999) while job satisfaction questionnaires was adopted from the study of Edward \& Rothbard (1999) and Weiss, et al. (1967).

\section{Procedure and Statistical Methods}

130 questionnaires were distributed among these employees out of whom 100 filled questionnaires were received forming percentage of $76.92 \%$. These properly filled questionnaires were used for data analysis in SPSS. Both descriptive statistics and multivariate analysis such as correlation and regression analysis were conducted to test the hypothesis.

\section{Results and discussions}

Both descriptive and multivariate analyses are performed to feel for the data and test the postulate hypothesis respectively.

\section{Frequency distribution of respondents}

Table 1 represents age distribution of the respondents. There were 11 respondents from the age group of 21-25 that formed a percentage of 11.14 of the respondents belonged to age group of 26-30 years forming a percentage is 14. Similarly, age group of 31-35 consisted of 21 respondents that formed 21 percent. In addition, 27 of the respondents belonged to age group of is 36-40 and their percentage is 27. Moreover, there were 7 respondents in the age group of 41-45 and 46-50 that formed a percentage of 7 . Furthermore, 5 of the respondents belonged to age of 51-55 and their percentage are 5 . There are 3 of the respondents belonged to age of 56-60 with the percentage of 3 . The remaining 5 of the respondents are above 60 years age and their percentage is 5 . In this table the total number of respondents is 100.

Table 1. Age of the respondents

\begin{tabular}{|l|l|l|l|l|}
\hline Years & Frequency & Percentage & Valid percentage & Cumulative percentage \\
\hline $21-25$ & 11 & 11.0 & 11.0 & 11.0 \\
\hline $26-30$ & 14 & 14.0 & 14.0 & 25.0 \\
\hline $31-35$ & 21 & 21.0 & 21.0 & 46.0 \\
\hline $36-40$ & 27 & 27.0 & 27.0 & 73.0 \\
\hline $41-45$ & 7 & 7.0 & 7.0 & 80.0 \\
\hline $46-50$ & 7 & 7.0 & 7.0 & 87.0 \\
\hline $51-55$ & 5 & 5.0 & 5.0 & 92.0 \\
\hline $56-60$ & 3 & 3.0 & 3.0 & 95.0 \\
\hline
\end{tabular}




\begin{tabular}{|l|l|l|l|l|}
\hline Above 60 & 5 & 5.0 & 5.0 & 100.0 \\
\hline Total & 100 & 100.0 & 100.0 & \\
\hline
\end{tabular}

Source: Authors' own research.

Table 2 shows the qualification of the respondents. There are 7 of the respondents having qualification intermediate and their percentage is 7. Similarly, 22 of the respondents are graduates and their percentage is 22 . In addition in this table 43 of the respondents are postgraduate with the percentage of 43. Furthermore, 19 of the respondents have qualification of MS- M phill with the percentage of 19, while 9 of the respondents have education of $\mathrm{PhD}$ with the percentage of 9. The total numbers of respondents are 100.

Table 2. Qualification of the respondents

\begin{tabular}{|l|l|l|l|l|}
\hline Qualification & Frequency & Percentage & Valid percentage & Cumulative percentage \\
\hline Intermediate & 7 & 7.0 & 7.0 & 7.0 \\
\hline Graduate & 22 & 22.0 & 22.0 & 29.0 \\
\hline Post graduate & 43 & 43.0 & 43.0 & 72.0 \\
\hline MS- M phill & 19 & 19.0 & 19.0 & 91.0 \\
\hline Phd & 9 & 9.0 & 9.0 & 100.0 \\
\hline Total & 100 & 100.0 & 100.0 & \\
\hline
\end{tabular}

Source: Authors' own research.

Table 3 describes the gender of the respondents. There are 87 of the employees' are male having percentage of 87, while 13 of the employees' are female having percentage of 13 and the total employees' are 100.

Table 3. Gender of the respondents

\begin{tabular}{|l|l|l|l|l|}
\hline Gender & Frequency & Percentage & Valid percentage & Cumulative percentage \\
\hline Male & 87 & 87.0 & 87.0 & 87.0 \\
\hline Female & 13 & 13.0 & 13.0 & 100.0 \\
\hline Total & 100 & 100.0 & 100.0 & \\
\hline
\end{tabular}

Source: Authors' own research.

Table 4 shows the experience of the respondents. There are 19 respondents having experience less than 1 years and their percentage is 19 . Similarly 25 of the respondents have experience of 1-2 years and their percentage is 25. Moreover, 35 of the respondents have experience 3-5 years and their percentage is 35. In addition 18 of the employees have 6-10 years of experience and their percentage is 18, while 3 of the respondents have over 10 years of experience and their percentage is 18 and the total numbers of respondents are 100.

Table 4. Experience of the respondents

\begin{tabular}{|l|l|l|l|l|}
\hline Experience & Frequency & Percentage & Valid percentage & Cumulative percentage \\
\hline Less than 1 years & 19 & 19.0 & 19.0 & 19.0 \\
\hline 1-2 year & 25 & 25.0 & 25.0 & 44.0 \\
\hline 3-5 years & 35 & 35.0 & 35.0 & 79.0 \\
\hline 6-10 years & 18 & 18.0 & 18.0 & 97.0 \\
\hline Over 10 years & 3 & 3.0 & 3.0 & 100.0 \\
\hline Total & 100 & 100.0 & 100.0 & Source: Authors' own research.
\end{tabular}




\section{Correlation analysis}

Table 5 shows the correlation between the dependent, job satisfaction, and independent variables, idealized influence, individualized consideration, inspirational motivation, and intellectual stimulation. The correlation matrix shows weak correlation of $-0.031,-0.262$, 0.084 , and -0.301 at 0.05 level between dependent (job satisfaction) and independent variables (idealized influence, individualized consideration, inspirational motivation, and intellectual stimulation). Thus the result suggests no significant association between job satisfaction and leadership types.

Table 5. Correlation analysis

\begin{tabular}{|l|l|l|l|l|l|}
\hline & $\begin{array}{l}\text { Idealized } \\
\text { influence }\end{array}$ & $\begin{array}{l}\text { Individualized } \\
\text { consideration }\end{array}$ & $\begin{array}{l}\text { Inspirational } \\
\text { motivation }\end{array}$ & $\begin{array}{l}\text { Intellectual } \\
\text { stimulation }\end{array}$ & $\begin{array}{l}\text { job } \\
\text { satisfaction }\end{array}$ \\
\hline $\begin{array}{l}\text { Idealized } \\
\text { influence }\end{array}$ & 1 & & & & \\
\hline $\begin{array}{l}\text { Individualized } \\
\text { consideration }\end{array}$ & $.466^{* *}$ & 1 & & & \\
\hline $\begin{array}{l}\text { Inspirational } \\
\text { motivation }\end{array}$ & $-0.049^{* *}$ &, $225^{* *}$ & 1 & 1 & \\
\hline $\begin{array}{l}\text { Intellectual } \\
\text { stimulation }\end{array}$ & $-0.134^{* *}$ & $-0.116^{* *}$ & $.187^{* *}$ & 1 & \\
\hline job satisfaction & $-0.031^{* *}$ & $-0.262^{* *}$ & $-0.084^{* *}$ & $.301^{* *}$ & 1 \\
\hline
\end{tabular}

** Correlation is significant at the 0.01 level (2-tailled).

** Correlation is significant at the 0.05 level (2-tailled).

Source: Authors' own research.

\section{Regression analysis}

Table 6 depicts model summary of multiple regression and overall fit statistics. In this table, the coefficient of determination, R2, shows the amount of variance in dependent variable by corresponding independent variables. The value of $\mathrm{R} 2=0.164$ shows that $16.4 \%$ variation in dependent variable is accounted for by independent variables. The extent of variance in the dependent and independent variable shows by Adjusted R square_ more strict criteria for measuring the amount of variance. The value of adjusted $\mathrm{R}$ square is 0.129 which shows that dependent variable explains $12.9 \%$ variations in explaining independent variable. The adjusted R-Square value is apparently not that high as expected. However, the job satisfaction being influence by a plethora of factors therefore the model will show high RSquare if other relevant factors are included in the model.

Table 6. Model Summary

\begin{tabular}{|l|l|l|l|l|}
\hline Mode 1 & R & R Square & Adjusted R Square & Std. Error of the Estimate \\
\hline 1 & $.409 \mathrm{a}$ & .164 & .129 & .82488 \\
\hline
\end{tabular}

a. Predictors: (Constant), intellectual stimulation, individualized consideration, inspirational motivation, idealized influence.

Source: Authors' own research.

The value of $\mathrm{F}$ in the below table no. 7 shows statistical significance of the model $(\mathrm{p}<$ $.05)$. The value of $F=4.655, p=.000(p<.05)$ shows that the model is statistically significant. 
Table 7. ANOVA

\begin{tabular}{|l|l|l|l|l|l|}
\hline Model & Sum of Squares & Df & Mean Square & F & Sig. \\
\hline Regression & 12.670 & 4 & 3.168 & 4.655 & $.000^{\mathrm{a}}$ \\
\hline Residual & 64.641 & 95 & .680 & & \\
\hline Total & 77.311 & 99 & & & \\
\hline
\end{tabular}

a. Predictors: (constant), intellectual stimulation, individualized consideration, inspirational motivation, idealized influence.

b. Dependent variable job satisfaction.

Source: Authors' own research.

Table 8 depicts summary of intercepts, multiple regression estimates, and significance level. Based on the value of $t$ statistic $>2$ and significance level $p<0.05$, the scholar decides upon the acceptance or rejection of hypothesis with $\mathrm{p}<.05$. Thus the leadership styles of idealized influence, individualized consideration, and inspirational motivation have $t$ statistic value $<2$ and significance level $p>0.05$ stand rejected. These leadership styles have non-significant impact on employees' job satisfaction. These findings are in contrast with that of Chen and Spector (1991), Brockner (1988) and DeCremer (2003), Al-Ababneh (2013), Yousaf (2000), Druskat (2000) and Ristow et al., (2003) who noted a positive association between transformational leadership and job satisfaction.

However, the only leadership style of intellectual stimulation meets the criteria of $t$ statistics $>2$ and significance level $\mathrm{p}<0.05$ which lead us to conclude that intellectual stimulation has significant impact on the level of employees' job satisfaction. Moreover, the standardized coefficient beta $(\beta)$ of 0.300 indicates that one unit change in intellectual stimulation will bring 0.30 unit change in employees' job satisfaction. This finding is in line with that of Chen and Spector (1991), Brockner (1988) and DeCremer (2003), Al-Ababneh (2013), Yousaf (2000), Druskat (2000) and Ristow et al., (2003) who noted a positive association between transformational leadership and job satisfaction.

Table 8. Coefficients

\begin{tabular}{|c|c|c|c|c|c|}
\hline \multirow[b]{2}{*}{ Model } & \multicolumn{2}{|c|}{ Unstandardized Coefficients } & \multirow{2}{*}{\begin{tabular}{|l|} 
Standardized Coefficients \\
Beta
\end{tabular}} & \multirow{2}{*}{ t } & \multirow[b]{2}{*}{ Sig. } \\
\hline & B & Std. Error & & & \\
\hline 1 (Constant) & 2.514 & .401 & & 6.271 & .000 \\
\hline idealized influence & 135 & .109 & .133 & 1.233 & .221 \\
\hline individualized consideration & -.309 & .126 & -.273 & -2.455 & .016 \\
\hline inspirational motivation & -.082 & .113 & -.072 & -.723 & .471 \\
\hline intellectual stimulation & .226 & .073 & .300 & 3.096 & .003 \\
\hline
\end{tabular}

a. Dependent Variable: job satisfactions

Source: Authors' own research.

\section{Conclusion}

The study was conducted to find the impact of transformational leadership on employees' job satisfaction in the public sectors universities of KPK, Pakistan. The result of the study showed that transformational leadership in terms of idealized influence, individualized 
consideration, and inspirational motivations had non-significant impact on employee's job satisfaction. However, intellectual stimulation had significant and positive impact on employees' job satisfaction. The paper contribution is two-fold that is contribution to the literature, and practitioners (universities) by paying more attention to the intellectual stimulation type of leadership to enhance their employees' satisfaction level. Future research should employ more data for analysis and possibly increase more relevant independent variables to explain sufficient variance in the dependent variables. Similarly, further research should tap on the reasons behind the non-significant relationship between transformational leadership and job satisfaction in terms of idealized influence, individualized consideration, and inspirational motivation that is widely noted as positive association. Moreover, it is acknowledged that the study is not free from limitations and has constrained in terms of limited data, finance, time, and access to respondents.

\section{References}

Al-Ababneh, M. (2013). Leadership style of managers in five-star hotels and its relationship with employees job satisfaction. Journal of Occupational and Organizational Psychology, 3(2), 93-98.

Ary, D., Jacobs, L. C., Irvine, C. K. S., \& Walker, D. (2013). Introduction to research in education. Cengage Learning.

Avolio, B. J., Walumbwa, F. O., \& Weber, T. J. (2009). Leadership: Current theories, research, and future directions. Annual review of psychology, 60, 421-449.

Avolio, B. J., \& Bass, B. M. (1998). You can drag a horse to water but you can't make it drink unless it is thirsty. Journal of Leadership Studies, 5(1), 4-17.

Bhat, A. B., Rangnekar, S., \& Barua, M. (2013). Impact of transformational leadership style on organizational learning. Elite Research Journal of Education and Review, 1(4), 2431.

Bono, J. E., \& Ilies, R. (2006). Charisma, positive emotions and mood contagion. The Leadership Quarterly, 17(4), 317-334.

Bono, J. E., \& Judge, T. A. (2003). Self-concordance at work: Toward understanding the motivational effects of transformational leaders. Academy of Management Journal, 46(5), 554-571.

Bruch, H., \& Walter, F. (2007). Leadership in context: Investigating hierarchical impacts on transformational leadership. Leadership \& Organization Development Journal, 28(8), 710-726.

Crawford, E. R., LePine, J. A., \& Rich, B. L. (2010). Linking job demands and resources to employee engagement and burnout: a theoretical extension and meta-analytic test. Journal of Applied Psychology, 95(5), 834-848.

Erez, A., Misangyi, V. F., Johnson, D. E., LePine, M. A., \& Halverson, K. C. (2008). Stirring the hearts of followers: charismatic leadership as the transferal of affect. Journal of applied psychology, 93(3), 602-615.

House, R. J., \& Aditya, R. N. (1997). The social scientific study of leadership: Quo vadis?. Journal of management, 23(3), 409-473.

Ilies, R., Judge, T., \& Wagner, D. (2006). Making sense of motivational leadership: The trail from transformational leaders to motivated followers. Journal of Leadership \& Organizational Studies, 13(1), 1-22.

DOI: 10.2478/picbe-2018-0032, pp. 363-373, ISSN 2558-9652| Proceedings of the $12^{\text {th }}$ International Conference on Business Excellence 2018 
Judge, T. A., \& Piccolo, R. F. (2004). Transformational and transactional leadership: a metaanalytic test of their relative validity. Journal of applied psychology, 89(5), 755.

Mahsud, R., Yukl, G., \& Prussia, G. (2010). Leader empathy, ethical leadership, and relationsoriented behaviors as antecedents of leader-member exchange quality. Journal of Managerial Psychology, 25(6), 561-577.

McColl-Kennedy, J. R., \& Anderson, R. D. (2002). Impact of leadership style and emotions on subordinate performance. The Leadership Quarterly, 13(5), 545-559.

Moghli, A. (2003). Proposing transformational leadership model in administrative organizations in Iran. Management Knowledge, 62, 77-100.

Mohammad Mosadegh Rad, A., \& Hossein Yarmohammadian, M. (2006). A study of relationship between managers' leadership style and employees' job satisfaction. Leadership in Health Services, 19(2), 11-28.

Mosadeghrad, A. M. (2003). Principles of health care administration. Dibagran Tehran, Tehran.

Sy, T., Côté, S., \& Saavedra, R. (2005). The contagious leader: impact of the leader's mood on the mood of group members, group affective tone, and group processes. Journal of applied psychology, 90(2), 295-305.

Tafvelin, S., Armelius, K., \& Westerberg, K. (2011). Toward understanding the direct and indirect effects of transformational leadership on well-being: A longitudinal study. Journal of Leadership \& Organizational Studies, 18(4), 480-492.

Thamrin, H. M. (2012). The Influence of Transformational Leadership and Organizational Commitment on Job Satisfaction and Employee Performance. International Journal of Innovation, Management and Technology, 3(5), 566-572.

Van Kleef, G. A., Homan, A. C., Beersma, B., Van Knippenberg, D., Van Knippenberg, B., \& Damen, F. (2009). Searing sentiment or cold calculation? The effects of leader emotional displays on team performance depend on follower epistemic motivation. Academy of Management Journal, 52(3), 562-580.

Walumbwa, F. O., \& Hartnell, C. A. (2011). Understanding transformational leadershipemployee performance links: The role of relational identification and selfefficacy. Journal of Occupational and Organizational Psychology, 84(1), 153-172.

Wang, G., Oh, I. S., Courtright, S. H., \& Colbert, A. E. (2011). Transformational leadership and performance across criteria and levels: A meta-analytic review of 25 years of research. Group \& Organization Management, 36(2), 223-270. 